\section{References}

Alexander-Marrack, P. D. \& Friend, P. F. 1976: Devonian sediments of East Greenland. III: The eastern sequence, Vilddal Supergroup and part of the Kap Kolthoff Supergroup. Meddr Grønland 206(3), 122 pp.

Bendix-Almgreen, S. E. 1976: Palaeovertebrate faunas of Greenland. In Escher, A. \& Watt, W. S. (edit.) Geology of Greenland, 536-573. Copenhagen: Geol. Surv. Greenland.

Birkelund, T. \& Perch-Nielsen, K. 1976: Late Palaeozoic Mesozoic evolution of central East Greenland. In Escher, A. \& Watt, W. S. (edit.) Geology of Greenland, 304-339. Copenhagen: Geol. Surv. Greenland.

Bjerring, H. C. 1985: Facts and thoughts on piscine phylogeny. In Foreman, R. E., Gorbman, A. \& Olsson, R. (edit.) Evolutionary biology of primitive fishes. NATO Adv. Stud. Inst. Ser. A, life sci. 103, 31-57. New York: Plenum Press.

Bütler, H. 1954: Die stratigraphische Gliederung der Mitteldevonischen Serien im Gebiete von Kap Franklin an Kejser Franz Joseph Fjord in Zentral-Ostgrönland. Meddr Grønland 116(7), $126 \mathrm{pp}$.

Clack, J. A. in press: New Tetrapod material from the Upper Devonian of East Greenland. Palaeontology.

Friend, P. F., Alexander-Marrack, P. D., Nicholsen, J. \& Yeats, A. K. 1976a: Devonian sediments of East Greenland. I: Introduction, classification of sequences, petrographic notes. Meddr Grønland 206(1), 56 pp.

Friend, P. F., Alexander-Marrack, P. D., Nicholson, J. \& Yeats, A. K. 1976b: Devonian sediments of East Greenland. II: Sedimentary structures and fossils. Meddr Grønland 206 (2), $91 \mathrm{pp}$.

Friend, P. F., Alexander-Marrack, P. D., Allen, K. C., Nicholson, J. \& Yeats, A. K. 1983: Devonian sediments of East Greenland. VI: Review of results. Meddr Grønland 206(6), $96 \mathrm{pp}$.

Jarvik, E. A. V. 1952: On the fish-like tail in the ichthyostegid stegocephalians, with description of a new stegocephalian and a new crossopterygian from the upper Devonian of East Greenland. Meddr Grønland 114(12), 90 pp.
Jarvik, E. A. V. 1961: Devonian vertebrates. In Raasch, G. O. (edit.) Geology of the Arctic 1, 197-204. Toronto U.P.

Jarvik, E. A. V. 1972: Middle and Upper Devonian Porolepiformes from East Greenland with special reference to Glyptolepis groenlandica n.sp, and a discussion on the structure of the head in the Porolepiformes. Meddr Grønland 187(2), 307 pp.

Jarvik, E. A. V. 1980: Basic structure and evolution of vertebrates 1, 575 pp. London: Academic Press.

Jarvik, E. A. V. 1985: Devonian osteolepiform fishes from East Greenland. Meddr Grønland Geosci. 13, 52 pp.

Lehman, J.-P. 1959: Les dipneustes du Dévonien supérieur du Groenland. Meddr Grønland 160(4), 58 pp.

Maync, W. 1942: Stratigraphie und Faziesverhältnisse der Oberpermischen Ablagerungen Ostgröenlands (Olim 'Oberkarbon-Unterperm') zwischen Wollaston Forland und den Kejser Josephs Fjord. Meddr Grønland 115(2), 128 pp.

Nicholson, J. \& Friend, P. F. 1976: Devonian sediments of East Greenland. V: The central sequence, Kap Graah Group and Mount Celsius Supergroup. Meddr Grønland 206(5), 118 pp.

Nielsen, E. 1935: The Permian and Eotriassic vertebrate-bearing beds at Godthaab Gulf (East Greenland). Meddr Grønland 98(1), $111 \mathrm{pp}$.

Peel, J. S. \& Yochelson, E. L. 1984: Permian Toxeomorphorida from Greenland: an appraisal of the molluscan class Xenoconchia. Lethaia 17, 211-221.

Stensiō, E. A. 1931: Upper Devonian vertebrates from East Greenland collected by the Danish Greenland expeditions in 1929 and 1930. Meddr Grønland 86(1), 212 pp.

Stensiö, E. A. 1936: On the Placodermi of the Upper Devonian of East Greenland. Supplement to part I. Meddr Grønland $97(2), 52 \mathrm{pp}$.

Warren, J. W. \& Wakefield, N. A. 1972: Trackways of tetrapod vertebrates from the Upper Devonian of Victoria, Australia. Nature, Lond. 238, 469-470.

Yeats, A. K. \& Friend, P. F. 1978: Devonian sediments of East Greenland. IV: The western sequence, Kap Kolthoff Supergroup of the western areas. Meddr Grønland 206(4), 112 pp.
S.E.B.-A.,

Geologisk Museum,

Øster Voldgade 5-7,

$D K-1350$ Copenhagen $K$, Denmark.
J.A.C.,

University Museum of Zoology,

Downing Street,

Cambridge CB2 3EJ, U.K:
H.O., Grønlands Geologiske Undersøgelse, $\emptyset$ ster Voldgade 10, DK-1350 Copenhagen $K$, Denmark.

\title{
Glacier velocities from aerial photographs in North and North-East Greenland
}

\author{
A. K. Higgins
}

General descriptions of the glaciers of North and North-East Greenland have been given by Koch (1928), Davies \& Krinsley (1962) and Weidick (1975). These descriptions, however, provide little in the way of quantitative data on glacier velocities, although Davies \& Krinsley concluded that a large number of glaciers and 


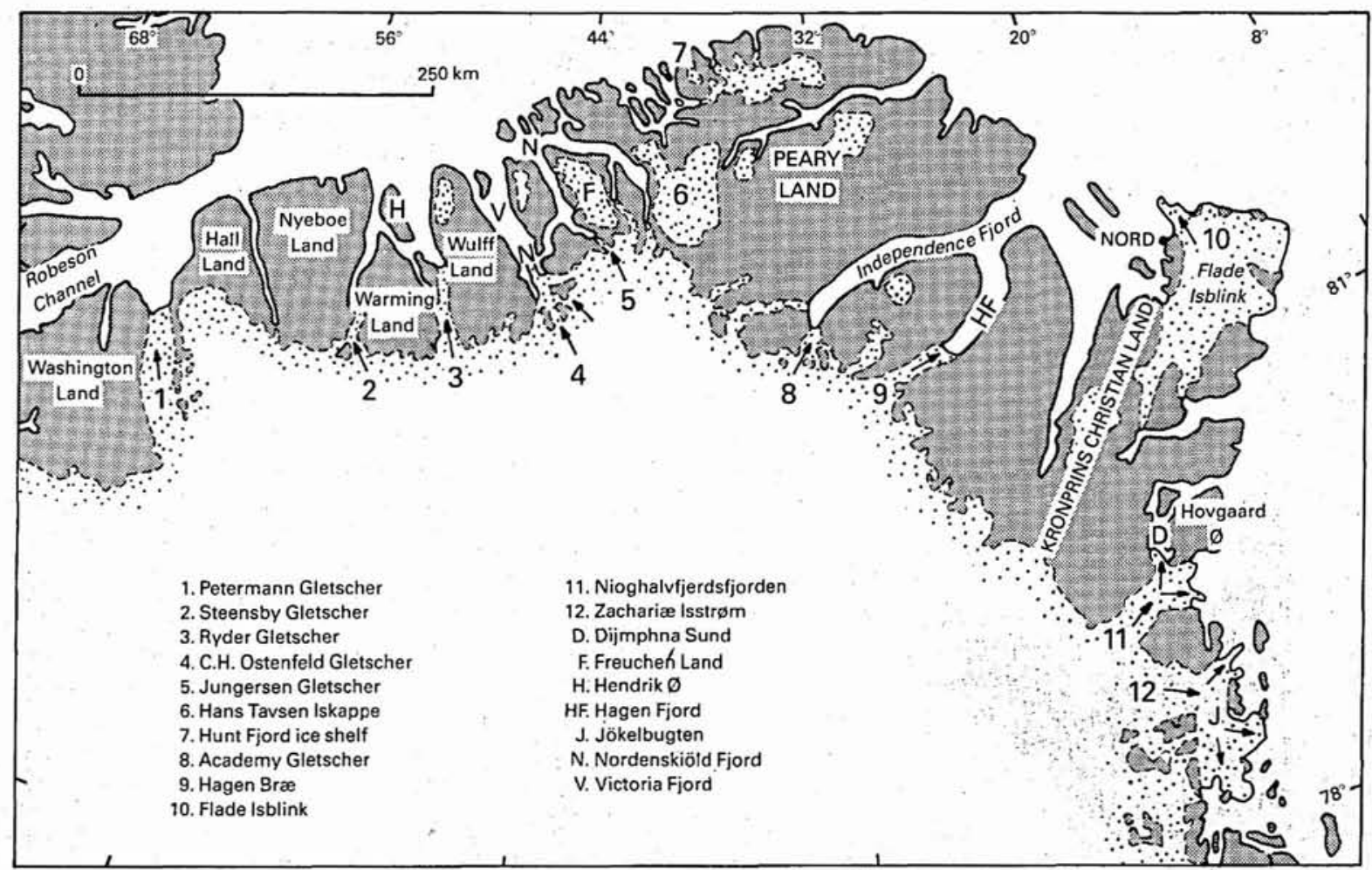

Fig. 1. Map of North and North-East Greenland showing location of glaciers described in text. Land areas are shaded. The marginal area of the Inland Ice and independent ice caps and glaciers have a dotted ornament.

small ice caps in North Greenland exhibited stable conditions, with a significant number showing evidence of recent retreat. Comparisons of vertical aerial photographs taken in 1959-63, 1971 and 1978 permit measurements of glacier velocity to be made on floating ice tongues which have preserved a distinctive surface pattern of meandering streams and crevasses. These show the largest glaciers draining the Inland Ice in North and North-East Greenland to have average velocities ranging from 300 to $900 \mathrm{~m} /$ year.

This study of vertical aerial photographs has also demonstrated that for floating glacier tongues the position of the glacier terminus is not a reliable indicator of advance or retreat. In the fjords of North Greenland semi-permanent sea ice often maintains the integrity of advancing floating glacier fronts for periods of ten to twenty years (Koch, 1928; Weidick, 1975); the break-up of the floating tongue in rare summers when the sea ice melts completely may give the impression of a sudden retreat, but this 'retreat' is unrelated to changes in the mass balance.

Petermann Gletscher (fig. 1: no. 1) is $110 \mathrm{~km}$ long and 15 $\mathrm{km}$ wide at its front, and occupies a deep cleft between
Washington Land and Hall Land. At least the northern $40 \mathrm{~km}$ of the glacier is afloat, and matching of surface features on aerial photographs from 1959 and $1978 \mathrm{dem}$ onstrate that the central part of the glacier has moved 17 $\mathrm{km}$ in 19 years, an average velocity of $895 \mathrm{~m} / \mathrm{year}$.

The position of the glacier terminus is reported to have had a fairly stable position since 1876 (Koch, 1928; Davies \& Krinsley, 1962), which indicates that large icebergs must regularly calve from the front and escape into Robeson Channel, where there is often open water in the summer.

Steensby Gletscher (fig. 1: no. 2) drains into the head of Sankt George Fjord, between Warming Land and Nyeboe Land. It is $62 \mathrm{~km}$ long, and about $3.5 \mathrm{~km}$ wide at the front where it characteristically breaks up into several floating lobes separated by aggregates of small icebergs (Ahnert, 1963). Aerial photographs from 1963, 1971 and 1978 demonstrate a velocity of $430 \mathrm{~m} /$ year. Ahnert's estimate of an annual advance of 5.4 to $8.7 \mathrm{~km}$ was based on an incorrect assumption. The semi-permanent sea ice has maintained the advancing front of Steensby Gletscher as an intact mass, and no large icebergs drifted away from the front between 1953 and 1978. 
Ryder Gletscher (fig. 1: no. 3) is more than $80 \mathrm{~km}$ long and drains northwards between Wulff Land and Permin Land, where it is $8 \mathrm{~km}$ wide. Characteristic surface features on the frontal floating segment of the glacier demonstrate a movement of up to $8 \mathrm{~km}$ between 1963 and 1978, an average velocity of about $535 \mathrm{~m} /$ year.

Lauge Koch's observations in 1917 showed the floating glacier tongue to extend a considerable distance farther north than at present, into the fjord between Hendrik $\emptyset$ and Wulff Land (Koch, 1928). Davies \& Krinsley (1962) note that this tongue had broken up prior to 1947 , and that the position of the glacier front withdrew a further $5 \mathrm{~km}$ from 1947 to 1956 . Between 1971 and 1978 the front has advanced without drift of significant icebergs away from the front.

Break-up and dispersal of the floating glacier tongue clearly takes place only in rare summers when the sea ice melts completely. Oblique aerial photographs from 1953 show a collection of large icebergs off the front of Ryder Gletscher, which in an ice-free summer prior to $1963 \mathrm{had}$ drifted 15 to $45 \mathrm{~km}$ northwards to positions between Hendrik $\varnothing$ and Wulff Land. These tabular icebergs occupied virtually unchanged positions on 1963 and 1978 aerial photographs and in 1985 (personal observations), showing the sea ice had not melted completely for at least 22 years.

C. H. Ostenfeld Gletscher (fig. 1: no. 4). In May 1917 Lauge Koch encountered in the outer part of Victoria Fjord what he initially took to be glacier ice from the floating tongue of C. H. Ostenfeld Gletscher, but later concluded it might be old sea ice (Koch, 1928). His first impression. was correct, and as shown by Davies \& Krinsley (1962) the inner $75 \mathrm{~km}$ of Victoria Fjord is tightly packed by large and small icebergs derived from the glaciers at the head of the fjord. The position of the iceberg front is currently much the same as in 1917.

Six large glaciers merge at the head of Victoria Fjord, of which the most important is C. H. Ostenfeld Gietscher; it is up to $7 \mathrm{~km}$ wide and has a more or less connected floating segment projecting for $25 \mathrm{~km}$ into Victoria Fjord. Velocity measurements made on the basis of aerial photographs from 1963, 1971 and 1978 range from 750 to $815 \mathrm{~m} /$ year. Two glaciers west of C. H. Ostenfeld Gletscher are inactive, whereas the three glaciers to the east have velocities of $400-550 \mathrm{~m} /$ year.

Jungersen Gletscher (fig. 1: no. 5). This is not a large glacier filling Nordenskiöld Fjord as depicted by Koch (1928), but as shown on modern maps it is a relatively small glacier $2.5 \mathrm{~km}$ wide draining from the Inland Ice south of Freuchen Land into the head of the fjord. The measured velocity determined from 1963 and 1978 vertical aerial photographs is $350 \mathrm{~m} / \mathrm{year}$.

Hans Tavsen Iskappe (fig. 1: no. 6) is an independent ice cap about $70 \mathrm{~km}$ across. Three small outlet glaciers draining into the fjord to the west have measured velocities of $40-70 \mathrm{~m} / \mathrm{year}$, and a larger glacier draining northwards $100 \mathrm{~m} /$ year. A drilling operation was carried out on Hans Tavsen Iskappe during the 1975 Greenland Ice Sheet Programme (Langway et al., 1985).

Hunt Fjord ice shelf (fig. 1: no. 7). Small ice shelves occur in northern Peary Land, one of which completely fills Hunt Fjord; a smaller ice sheif partially blocks the sound west of Hunt Fjord. These are the only ice shelves in North Greenland which bear comparison with the better known ice shelves fringing northern Ellesmere Island (Jeffries, 1987). Like them they appear to be very ancient features and exhibit a comparable surface pattern of undulating ridges and water-filled hollows. However, the North Greenland ice shelves are clearly fed by the alpine glaciers in north Peary Land, and while they generally show little sign of movement between 1963 and 1978 aerial photographs, a glacier feeding a portion of the west front of Hunt Fjord ice shelf is moving forward at $23 \mathrm{~m} / \mathrm{year}$.

Academy Gletscher (fig. 1: no. 8). Early observations of the $10 \mathrm{~km}$ wide glacier at the head of Independence Fjord indicate a floating frontal portion of hummocky ice and densely packed icebergs, extending about $12 \mathrm{~km}$. into the fjord (Peary, 1898; Freuchen, 1915; Koch, 1928). This floating portion of Academy Gletscher had dispersed by 1956 (Davies \& Krinsley, 1962), and aerial photographs from 1962 and 1978 show no indication of re-establishment: It is inferred that since the 1950 s the fjord ice has melted sufficiently frequently that floating segments of the glacier disintegrate and disperse before they can form substantial ice tongues. No velocity measurements are possible on aerial photographs of the present crevassed frontal portion.

Hagen Brae (fig. 1: no. 9), at the head of Hagen Fjord, is $75 \mathrm{~km}$ long and about $10 \mathrm{~km}$ wide in its central part. Towards the front the glacier widens, and while the southern part is partially dammed by two islands and breaks up, the northern part of the front continues into the fjord as a floating segment $6 \mathrm{~km}$ wide and up to 18 $\mathrm{km}$ long. Davies \& Krinsley (1962) describe the floating glacier tongue as stagnant with a surface of interlacing streams and large interconnecting ponds in parallel troughs. Aerial photographs from 1960 and 1978 show 
that Academy Gletscher with its floating front is moving outwards at $540 \mathrm{~m} /$ year. Large tabular icebergs up to 5 $\mathrm{km}$ by $2 \mathrm{~km}$ in size, which formed the front of the glacier tongue in 1960, had broken free and drifted up to $45 \mathrm{~km}$ towards the outer part of Hagen Fjord by 1978.

Flade Isblink (fig. 1: no. 10). Northern Kronprins Christian Land supports a large independent ice cap, Flade Isblink. It is more than $100 \mathrm{~km}$ long and up to $75 \mathrm{~km}$ wide but has only a few outlet glaciers which reach the sea, the most important being that east of Station Nord where a floating glacier up to $25 \mathrm{~km}$ broad extends northwards into the sea for up to $15 \mathrm{~km}$. The eastern lobe of this floating glacier moves at $175 \mathrm{~m}$ annually and the western lobe at $360 \mathrm{~m}$ annually. There was no significant loss from the advancing front between 1961 and 1978, although extensive open water leads were adjacent to the front on the 1978 aerial photographs.

Nioghalvfjerdsfjorden (fig. 1: no. 11). The interior of Nioghalvfjerdsfjorden is filled by an extensive floating glacier tongue, of which a northern branch projects into Dijmphna Sund west of Hovgaard $\emptyset$. The main glacier is $60 \mathrm{~km}$ long and $18 \mathrm{~km}$ wide at its narrowest point. It widens eastwards and the outer $30 \mathrm{~km}$ segment is afloat. A prominent system of undulating ridges and hollows, first described by Koch \& Wegener (1911), is developed on the surface of the floating glacier.

The velocity of parts of the main glacier have been measured from 1962 and 1978 aerial photographs at $310-330 \mathrm{~m} /$ year. The main floating front of the glacier in Nioghalvfjerdsfjorden abuts against a series of small islands. On the north side of the fjord movements of only $35-40 \mathrm{~m} / \mathrm{year}$ have been measured, whereas on the south side of the fjord tongues of ice projecting between islands move seawards at rates of up to $160 \mathrm{~m} /$ year. The branch of the glacier moving north into Dijmphna Sund has an average velocity of $210-230 \mathrm{~m} /$ year.

Zacharia Isstrøm/Jökelbugten (fig. 1: no. 12). The largest area of floating glacier ice in Greenland is that filling Jökelbugten, which emanates from Zachariæ Isstrøm. This area of ice-covered sea was initially de- scribed by Koch \& Wegener (1911) as 'Das schwimmende Indlandeis der Jökelbugt', and was classified by Koch (1928) as 'confluent ice'. The floating glacier ice cover a region $100 \mathrm{~km}$ from north to south and a maximum of $50 \mathrm{~km}$ from east to west.

Zachariæ Isstrøm has a minimum width of $20 \mathrm{~km}$, and the central active stream has a velocity estimated from 1963 and 1978 vertical aerial photographs to be at least $470 \mathrm{~m} / \mathrm{year}$. The northern part of the floating glacier ice is a single intact mass whose outward expansion is hindered by large and small islands. Between the islands narrow tongues of shelf ice up to $15 \mathrm{~km}$ long move outwards at $220-280 \mathrm{~m} / \mathrm{year}$. The southern area of floating glacier ice filling Jökelbugten comprises tightly packed, broken, tabular icebergs. Movement of individual icebergs varies from $66 \mathrm{~m}$ to $600 \mathrm{~m} / \mathrm{year}$ averaged over 15 years, the rate of movement being clearly related to the damming effect of islands, and large icebergs trapped between islands.

\section{References}

Ahnert, F. 1963: The terminal disintegration of Steensby Gletscher, North Greenland. J. Glaciol. 4, 537-545.

Davies, W. E. \& Krinsley, D. B. 1962: The recent regimen of the ice cap margin in North Greenland. Publs int. Ass. Scient. Hydrol. 58, 119-130.

Freuchen, P. 1915: General observations as to natural conditions in the country traversed by the expedition. Meddr Gronland 51(9), 361-369.

Jeffries, M. O. 1987: The growth, structure and disintegration of Arctic ice shelves. Polar Rec. 23, 631-649.

Koch, J. P. \& Wegener, A. 1911: Die glaciologischen Beobachtungen der Danmark-Expeditionen: Meddr Grønland 46(1), 1-77.

Koch, L. 1928: Contributions to the glaciology of North Greenland. Meddr Grønland 65(2), 181-464.

Langway, C. C., Jr., Oeschger, H. \& Dansgaard, W. 1985: The Greenland Ice Sheet Program in perspective. Monogr. Amer. geophys. Un. 33, 1-8.

Peary, R. A. 1898: Northward over the 'Great Ice', 521 \& 625 pp. New York: F. A. Stokes.

Weidick, A. 1975: A review of Quaternary investigations in Greenland. Inst. Polar Stud. Rep. 55, 161 pp. 